\title{
Okul Yöneticilerinin Maarif Müfettişlerine Yönelik Etkileme Taktikleri
}

\author{
Principals' Influence Tactics towards Educational \\ Supervisors
}

\begin{abstract}
Ali ÜNAL*, Gökhan ÖZASLAN**
Öz: Bu araştırmanın amacı, maarif müfettişlerinin bakışıyla (a) okul yöneticilerinin maarif müfettişlerine yönelik etkileme taktikleri kullanıp kullanmadıklarını, (b) kullanıyorlarsa hangi taktikleri kullandıklarını, (c) taktik seçiminde belirleyici olan etmenlerin neler olduğunu ve (d) kullanılan taktiklerin araştırmaya katılan müfettişler üzerindeki etkilerini ortaya çıkarmaktır. Nitel araştırma metodolojisi ile yürütülen araştırmanın verileri İç Anadolu Bölgesinde bir ilde görev yapmakta olan 9 maarif müfettişi ile yapılan yarı yapılandırılmış görüşmelerle toplanmıştır. Araştırma bulguları "Okul Yöneticilerinin kullandıkları taktikler ve bu taktiklerin müfettişler üzerindeki etkileri”ve"Okul yöneticilerinin etkileme taktikleri seçimlerinde belirleyici olan etmenler" kategorileri kapsamında ortaya konmuştur. Araştırma bulguları okul yöneticilerinin maarif müfettişlerine karşı (a) müfettişi hoș tutmak, (b) kendi başarılarını sergilemek, (c) gücünü hissettirmek ve (d) müfettişle ortak noktalar üzerinden yakınlık kurmak şeklinde dört temel taktik kullandıklarını göstermektedir.

Anahtar Kelimeler: Etkileme taktikleri, maarif müfettişleri, okul yöneticileri, denetim
\end{abstract}

\begin{abstract}
The aim of this study is to understand from the perspectives of educational supervisors that (a) whether or not principals use influence tactics towards educational supervisors, and if so, (b) what are these tactics, (c) what are the factors that affect the selection of the tactics, and (d) what are the effects of those tactics on the participants. Data of this qualitative study were gathered through semi-structured interviews with 9 educational supervisors working in a central Anatolian province of Turkey. Study findings were presented under the broad categories of "Tactics used by principals and their influence on educational supervisors"and"Factors that are determinative in principals' selection of tactics". Findings revealed that principals used four tactics, namely (a) treating the supervisor well, (b) exhibiting his/her own achievements, (c) implying his/her power, and (d) establishing intimacy with the supervisor by mentioning their similar backgrounds.

Keywords: Influence tactics, educational supervisors, principals, supervision
\end{abstract}

\section{Giriş}

Eğitim sistemlerinin neredeyse tamamında, hükümetlerin ve eğitim yöneticilerinin aldıkları kararların ve yapılan uygulamaların sonuçlarını izleyerek değerlendirmek için denetim uygulamaları vardır. Denetim sonucunda yapılan değerlendirmeler, ülkelere göre farklılık göstermekle birlikte genelde eğitim çalışanlarının atanma ve yükselmeleri, okul yönetimlerinin ve öğretim uygulamalarının geliştirilmesi, öğrencilerin ne derecede öğrendikleri ve velilerin ve toplumun bilgilendirilmesine yönelik araç olarak kullanılmaktadır. Hangi amaç için kullanılırsa kullanılsın, denetim sonucunda yapılan değerlendirmelerin, okul müdürlerinin atanma ve yükselmelerinde veya okuldaki öğretim uygulamalarının geliştirilmesinde ya da her ikisinde birden etkisi olduğu söylenebilir. Sonuçta; okul müdürleri için denetimler sonucunda kendisi ve okulundaki öğretim uygulamalarının olumlu şekilde değerlendirilmesi önemlidir. Bu nedenle, Robbinsve Judge'nin (2012) ifade ettiği gibi, okul denetimi sırasında okul müdürü ve diğer çalışanların, amaçlarını ve çıkarlarını destekleyecek şekilde örgütsel veya denetim kararlarını

\footnotetext{
*Doç.Dr., Necmettin Erbakan Üniversitesi, Ahmet Keleşoğlu Eğitim Fakültesi, Konya-Türkiye, e-posta: aliunal@konya.edu.tr

**Yrd.Doç.Dr., Necmettin Erbakan Üniversitesi, Ahmet Keleşoğlu Eğitim Fakültesi, Konya-Türkiye, e-posta: ozaslangokhan@gmail.com
} 
etkilemek için her türlü aracı kullanmaları beklenir. Örgütsel kararları etkilemek için yapılan davranış veya kullanılan araçlar, alanyazında "etkileme taktiği" olarak adlandırılmaktadır. Etkileme taktiği, üstlerden astlara olduğu gibi, astlardan üstlere doğru ya da eşit konumda olan kişiler arasında da kullanılabilmektedir (Yukl ve Tracey, 1992).

Türkiye'de okullar, maarif müfettişleri tarafından; yolsuzluk ve usulsüzlükleri önleyici, eğitici ve rehberlik yaklaşımı ile iyileştirici ve geliştirici yönde katkı sağlamak esasına dayalı olarak performans ve uygunluk denetimine tabi tutulmaktadır (MEB, 2014). Okul müdürlerinin, bu denetimler sırasında maarif müfettişlerinin kendileri ve okulları hakkında olumlu bir izlenim edinmeleri, yaptıkları çalışmaların uygunluğunu onaylayarak üst düzey performans sergilediklerine ilişkin rapor yazmaları için etkileme taktikleri kullanmaları olasıdır. Bu nedenle okul müdürlerinin maarif müfettişlerini etkileme taktikleri, bu araştırmanın konusu olarak seçilmiştir.

Higgins, Judge ve Ferris (2003) etkileme taktiklerini elli yıl kadar önce ErvingGoffman'ın davranış bilimlerine insanların kişiler arası ilişkilerde bilinçli olarak başkaları üzerinde belirli izlenimler bıraktıkları fikrini ortaya atmasına kadar götürmekte ve seksenli yıllardan itibaren de örgüt ortamında insan davranışlarını daha iyi anlayabilmek için ele alınmaya başlandığını belirtmektedirler. Alshenaifi ve Clarke (2014), Richard Mowday'in 1978 tarihli araştırmasını üstlere yönelik etkileme davranışına odaklanan ilk araştırmalardan biri olarak nitelemektedir. Diğer taraftan, Higgins, Judge ve Ferris (2003), uzun sayılabilecek bir süredir araştırmalara konu olan etkileme taktiklerinin ne olduğu ya da nasıl ölçülebileceği gibi konularda henüz fikir birliğine varılmadığını belirtmektedirler.

Etkileme taktiği, "Bir kişinin bir başkasının tutum ve davranışlarını etkilemek üzere kullandığı davranış tipi” olarak tanımlanmaktadır (Yukl, Chavez ve Seifert, 2005, 705). Etkileme taktiği ile ilişkili, ancak ondan farklı bir diğer kavram ise güçtür. Güç, kişinin diğerlerine istediklerini yaptırabilme becerisidir (Hoy ve Miskel, 2010). Somech ve DrachZahavy (2002) güç ve etkileme davranışı arasındaki farkı, gücün hedef kişileri istenilen yönde harekete geçirme potansiyeli, etkileme davranışının ise etkilemeye çalışan kişinin bu amaca yönelik bilfiil davranışı olması şeklinde açıklamışlardır. Etkileme taktikleri alanyazını incelendiğinde, taktik tanımları ve sınıflandırmalarının bir dizi çalışma sonucunda ortaya çıktığı görülmektedir. Söz konusu çalışmalar Tablo 1'deözetlenmiştir.

Tablo 1'de görüldüğü gibi etkileme taktikleri ile ilgili çalışmalar, ilk olarak 1980 yılında Kipnis, Schmidt ve Wilkinson'un Örgütsel Etkileme Stratejileri Profili Ölçeği’ni geliştirmeleri ile başlamıştır (Higgins, Judge ve Ferris, 2003). Örgütsel Etkileme Stratejileri Profili Ölçeği'ndeki sınıflamada sekiz etkileme taktiği bulunmaktadır (Higgins vd., 2003):

Dayatmacılık (Assertiveness). Etkilemeye çalışan kişinin zorlayıcı bir tavırla hedef kişiye istediğini yaptırması,

Yaranma (Ingratiation). Etkilemeye çalışan kişinin istediğini elde edebilmek için hedef kişinin kendisini sevmesini sağlayacak davranışlar ya da dostça tavırlar sergilemesi,

Mantıkla ikna (Rationality). Etkilemeye çalş̧an kişinin, hedef kişiye isteklerini destekleyen mantıklı bir argüman oluşturmak için veri ve bilgiler kullanması,

Yaptırım (Sanctions). Etkilemeye çalışan kişinin isteklerini kabul ettirebilmek için hedef kişiye yönelik ceza ya da ceza tehditlerine başvurması,

Takas (Exchange). Etkilemeye çalışan kişinin, hedef kişiye isteklerinin yerine getirilmesi karşılığında başka bir şey yapmayı açıkça teklif etmesi,

Üstlerine başvurma (Upwardappeals). Etkilemeye çalışan kişinin isteklerini yaptırabilmek için üstlerinin yardımına başvurması,

Engelleme (Blocking). Etkilemeye çalışan kişinin zorluklar çıkararak hedef kişinin çalışmalarını durdurmayı denemesi ve

Başkalarıyla birleşme (Coalitions). Etkilemeye çalışan kişinin hedef kişiyi ikna edebilmek için başka kişileri kendisine yardım etmek üzere harekete geçirmesidir. 
Tablo 1. Etkileme Taktikleri İle İlgili Araştırmalar ve Tespit Edilen Taktikler

\begin{tabular}{|c|c|c|c|c|}
\hline \multirow[b]{2}{*}{ Taktikler } & \multicolumn{4}{|c|}{ Araştırmalar } \\
\hline & $\begin{array}{l}\text { Örgütsel Etkileme } \\
\text { Stratejileri Profili Ölçeği } \\
\text { (Kipnis, Schmidt ve } \\
\text { Wilkinson,1980) }\end{array}$ & $\begin{array}{l}\text { Etkileme } \\
\text { Davranış1 } \\
\text { Ölçeği } \\
\text { (Yukl, } \\
\text { Lepsinger ve } \\
\text { Lucia, 1992) }\end{array}$ & $\begin{array}{c}\text { Üstlere Yönelik } \\
\text { Etkileme } \\
\text { Stratejileri } \\
\text { (Ralston, } \\
\text { Gustafson, } \\
\text { Mainiero ve } \\
\text { Umstot, 1993) }\end{array}$ & $\begin{array}{c}\text { Sanal } \\
\text { Ortamlarda } \\
\text { Başvurulan } \\
\text { Etkileme } \\
\text { Taktikleri } \\
\text { (Steizel ve } \\
\text { Rimbau- } \\
\text { Gilabert, } \\
\text { 2013) }\end{array}$ \\
\hline Mantıkla ikna & $\checkmark$ & $\checkmark$ & $\checkmark$ & $\checkmark$ \\
\hline Yaranma & $\checkmark$ & $\checkmark$ & $\checkmark$ & \\
\hline $\begin{array}{l}\text { Başkalarıyla } \\
\text { birleşme }\end{array}$ & $\checkmark$ & $\checkmark$ & & $\checkmark$ \\
\hline Dayatmacıllk & $\checkmark$ & $\checkmark$ & & \\
\hline Takas & $\checkmark$ & $\checkmark$ & & \\
\hline Yaptırım & $\checkmark$ & & & \\
\hline $\begin{array}{l}\text { Üstlerine } \\
\text { başvurma }\end{array}$ & $\checkmark$ & & & \\
\hline Engelleme & $\checkmark$ & & & \\
\hline İlham verme & & $\checkmark$ & & \\
\hline İstişare & & $\checkmark$ & & \\
\hline Arkadaşlığını & & $\checkmark$ & & \\
\hline kullanma & & & & \\
\hline Meşrulaştırma & & $\checkmark$ & & \\
\hline İș birliği & & $\checkmark$ & & \\
\hline Olas1 & & $\checkmark$ & & \\
\hline $\begin{array}{l}\text { kazanımlara } \\
\text { ilisskin }\end{array}$ & & & & \\
\hline bilgilendirme & & & & \\
\hline İyi asker & & & $\checkmark$ & \\
\hline İmaj yönetimi & & & $\checkmark$ & \\
\hline Çevre oluşturma & & & $\checkmark$ & \\
\hline $\begin{array}{l}\text { Bilgi akışını } \\
\text { idare etmek }\end{array}$ & & & $\checkmark$ & \\
\hline $\begin{array}{l}\text { Belden aşağ } 1 \\
\text { vurma }\end{array}$ & & & $\checkmark$ & \\
\hline $\begin{array}{l}\text { Araya başkasını } \\
\text { koyma }\end{array}$ & & & & $\checkmark$ \\
\hline
\end{tabular}

Farklı taktik tanımları içeren bir diğer çalışma ise Yukl, Lepsinger ve Lucia (1992) tarafından geliştirilen Etkileme Davranışı Ölçeği'dir. Söz konusu taktiklerden, yaranma, takas, başkalarıyla birleşme, dayatmacılık ve mantıkla ikna taktikleri -isimleri biraz farklı da olsaÖrgütsel Etkileme Stratejileri Profili Ölçeği içerisinde de geçmektedir. Örgütsel Etkileme Stratejileri Profili Ölçeği içerisinde geçmeyen ve sadece Etkileme Davranışı Ölçeği içerisinde geçen taktikler şunlardır (Yukl, Seifert ve Chavez, 2008):

Illham verme (Inspirationalappeals).Etkilemeye çalışan kişi istediklerini yaptırabilmek için hedef kişinin değerlerine ve ideallerine hitap etmeye çalışır.

İstişare (Consultation):Etkilemeye çalışan kişi hedef kişinin desteğini gerektiren bir etkinlik ya da değişiklik için hedef kişiden planlamaya yardım etmesini ya da iyileştirmeler önermesini ister.

Arkadaşlığını kullanma (Personalappeals). Etkilemeye çalışan kişi arkadaşlığına dayanarak hedef kişiden isteğini erine getirmesini ya da önerisini desteklemesini ister.

Meşrulaştırma (Legitimating).Etkilemeye çalışan kişi isteğini meşrulaştırmaya ya da söz konusu istekte bulunma yetkisinin olduğunu kanıtlamaya çalışır. 
Işs birliği (Collaboration). Etkilemeye çalışan kişi hedef kişiye isteğini yerine getirmesi ya da önerisini desteklemesi karşılığında kaynaklar ve yardım sunmayı teklif eder.

Olası kazanımlara ilişkin bilgilendirme (Apprising). Etkilemeye çalışan kişi istediklerini yapması ya da önerisini desteklemesi halinde hedef kişinin ulaşacağ 1 bireysel kazanımları açılar. Yukl, Chavez ve Seifert'e (2005) göre bu son taktik takas ve mantıkla ikna taktiklerine çok benzemekle birlikte bunlardan farklıdır. Olası kazanımlara ilişkin bilgi verme taktiğinde, hedefin deneyim kazanmak gibi ulaşacağı yan ürünlere odaklanılırken; takas taktiğindeetkilemeye çalışanın doğrudan vereceği şeylere odaklanılır. Mantıkla ikna taktiği, bir görevin başarıyla tamamlanmasının vereceği içsel doyuma odaklanırken, olası kazanımlara ilişkin bilgilendirme, hedefin ulaşacağı somut kazanımlara odaklanmaktadır.

Etkileme taktikleri kültürler arası çalışmalara da konu olmuştur. Böylesi çalışmalar için gereken ölçek Ralston, Gustafson, Mainiero ve Umstot (1993) tarafından "Üstlere Yönelik Etkileme Stratejileri Ölçeği" adıyla geliştirilmiştir. Söz konusu araştırmacılar, ABD ve Hong Kong'dan elde ettikleri verileri kullanarak yedi adet taktik belirlemişlerdir. Bunlar arasından mantıkla ikna ve yaranma taktikleri, diğer ölçekler kapsamında da tanımlanmıştır. Bu ölçek içerisinde diğerlerinden farklı olarak tanımlanan beş taktik şunlardır (Ralston, Giacalone ve Terpstra, 1994): sıkı çalışır.

İyi asker (GoodSoldier). Etkilemeye çalışan kişi örgütün de fayda sağlayacağı şekilde

İmaj yönetimi (Image Management). Etkilemeye çalışan kişi bütün örgütün gözünde olumlu bir izlenim oluşturur.

Çevre oluşturma (Personal Networking). Etkilemeye çalışan kişi sosyal çevre oluşturur ve bundan yararlanır.

Bilgi akışını idare etmek (Information Control). Etkilemeye çalışan kişi kendi yararı için başkalarının belirli bilgilere ulaşmasını engeller.

Belden aşağ vurma (Strong-ArmCoercion). Etkilemeye çalışan kişi şantaj ve benzeri yasadış1 yollara başvurur.

Son olarak; Steizel ve Rimbau-Gilabert (2013), sanal ortamlarda başvurulan etkileme taktiklerine odaklanan araştırmalarında sıkça başvurulan üç taktik bulmuşlardır. Bunlardan ikisi, önceki araştırmalarda da geçen mantıkla ikna (rationality) ve başkalarıyla birleşme (coalition) iken, "araya başkasını koyma" (intermediation) üçüncü bir taktik olarak araştırmacılar tarafından bulunmuştur. Bu taktik, başkalarıyla birleşme taktiğine çok benzemekle birlikte yöneticiye fiziken ya da sosyal anlamda yakın ve bu nedenle onu ikna edebilecek tek bir kişiyi öngörmesi bakımından başkalarıyla birleşme taktiğinden farklılaşmaktadır.

Castro, Douglas, Hochwarter, Ferris ve Frink (2003) ise, etkileme taktiklerini sert, yumuşak ve mantığa dayalı olmak üzere üç kategoriye ayırmaktadırlar. Yumuşak taktikler kullanıldığında hedef kişinin kendisinden istenenleri yapıp yapmamaya karar verme serbestisi daha fazla olmaktadır (Van Knippenberg ve Steensma, 2003). Yaranma, yumuşak taktik kategorisine; dayatmacılık, üstlerine başvurma ve başkalarıyla birleşme sert taktik kategorisine; mantıkla ikna ise mantığa dayalı kategorisine girmektedir. Takas, kimilerine göre yumuşak, kimilerine göre mantığa dayalı kategorilerine dâhil edilmektedir (Steizel ve Rimbau-Gilabert, 2013).

Taktik seçimine etki eden etmenler, ilgili alanyazının önemli bir bölümünü oluşturmaktadır. Bu çalışmada taktik seçimine etki eden etmenlere ilişkin araştırmalar, "Taktik seçimi üzerinde etkili olan bireysel özellikler", "Taktik seçimi üzerinde etkili olan etkileşim özellikleri" ve "Taktik seçimi üzerinde etkili olan örgüt özellikleri" olarak üç başlık altında kategorize edilmiş ve Tablo 2'de sunulmuştur.

Hangi etkileme taktiğinin hangi sonucu beraberinde getirdiği konusu da ilgili alanyazında sıkça ele alınmıştır. Örneğin, araştırmalarda yaranma taktiğinin kariyer başarısında olumlu etkilerinin olduğu (Judge ve Bretz, 1994) üstlerin kötü muameleleri ile astların üstlerine karşı şiddetli etkileme taktikleri kullanmaları arasında pozitif yönde bir ilişki olduğu (Yagil, 2006) ya da astların üstlerine yönelik etkileme taktiklerinin, terfi değerlendirmelerinde önemli bir rol oynadığı (Thacker ve Wayne, 1995) sonuçları elde edilmiştir. Alshenaifi ve Clarke 
(2014) da gerçekleştirdikleri meta-analiz sonucunda, genel olarak mantıkla iknanın daha fazla sayıda olumlu, dayatmacılı̆̆ın ise daha fazla sayıda olumsuz sonuç getiren taktikler olarak görülebilecekleri sonucuna ulaşmışlardır. Falbe ve Yukl (1992) ise taktiklerin tek başlarına kullanımının yanı sıra kombine kullanımlarına odaklanmış ve -örneğin- mantıkla ikna taktiğinin tek başına ya da sert taktiklerle kullanımına oranla yumuşak taktikler olarak bilenen istişare, ilham verme ya da yaranma ile birlikte kullanıldığında çok daha etkili olduğunu görmüşlerdir. Yine aynı araştırmada, sert taktiklerin genel olarak yumuşak taktiklerden daha az etkili olduğu da ortaya çıkmıştır. Yumuşak taktiklerin olumlu etkisine Higgins, Judge ve Ferris'in (2003) meta-analiz bulguları arasında da rastlanmakta, yaranma ve mantıkla iknanın tutarlı bir şekilde olumlu sonuçlarla ilişkili olduğu görülmektedir.

Tablo 2. Taktik Seçimine Etki Eden Etmenlerle Ilgili Araştırmalar

\begin{tabular}{|c|c|c|}
\hline Kategori & Arasstırmanın Odağı & Arasstırmalar \\
\hline \multirow{7}{*}{$\begin{array}{l}\text { Taktik seçimi } \\
\text { üzerinde etkili } \\
\text { olan bireysel } \\
\text { özellikler }\end{array}$} & A/B Kişilik tipi etkisi & - $\quad$ Aydın ve Pehlivan (2010) \\
\hline & Ait olunan kültür & $\begin{array}{ll}- & \text { Egri, Ralston, Murray ve Nicholson (2000) } \\
\text { - } & \text { Ralston, Giacalone ve Terpstra (1994) } \\
\text { - } & \text { Ralston, Hallinger, Egri ve Naothinsuhk (2005) } \\
\text { - } & \text { Ralston, Vollmer, Srinvasan, Nicholson, Tang } \\
& \text { ve Wan (2001) } \\
\text { - } & \text { Ralston, Gustafson, Mainiero ve Umstot (1993) } \\
\end{array}$ \\
\hline & Cinsiyet & $\begin{array}{ll}\text { - } & \text { Akhtar ve Mahmood (2009) } \\
\text { - } & \text { Aydın ve Pehlivan (2010) } \\
\text { - } & \text { Castro, Douglas, Hochwarter, Ferris ve Frink } \\
& (2003) \\
\text { - } & \text { Van Knippenberg ve Steensma (2003) } \\
\text { - } \quad \text { Kuru Çetin ve Çınkır (2014) } \\
\text { - Smith, Watkins, Burke, Christian, Smith, Hall } \\
\quad \text { ve Simms (2013) }\end{array}$ \\
\hline & Hiyerarşik pozisyon & $\begin{array}{ll}- & \text { Yukl ve Falbe (1990) } \\
\text { - } & \text { Yukl ve Tracey (1992) } \\
\end{array}$ \\
\hline & $\begin{array}{c}\text { Kişilik yapısı/Beş faktör } \\
\text { modeli }\end{array}$ & - Cable ve Judge (2003) \\
\hline & $\begin{array}{c}\text { Makyavelizm ve eğitim } \\
\text { düzeyi }\end{array}$ & - Farmer, Maslyn, Fedor ve Goodman (1997) \\
\hline & Yaş & $\begin{array}{ll}\text { - } & \text { Akhtar ve Mahmood (2009) } \\
\text { - } & \text { Lewis ve Ryan (2014) } \\
\text { - } & \text { Ralston vd. (2005) } \\
\end{array}$ \\
\hline \multirow{4}{*}{$\begin{array}{c}\text { Taktik seçimi } \\
\text { üzerinde etkili } \\
\text { olan etkileşim } \\
\text { özellikleri }\end{array}$} & $\begin{array}{l}\text { Ast ve üstün karşl1ıklı } \\
\text { güç dengesi ile ilişkisi }\end{array}$ & - Somech ve Drach-Zahavy (2002) \\
\hline & $\begin{array}{c}\text { Etkilemeye çalışan ve } \\
\text { hedef arasındaki ilişkinin } \\
\text { niteliği }\end{array}$ & $\begin{array}{l}\text { - Van Knippenberg, Knippenberg, Blaauw ve } \\
\text { Vermunt (1999) }\end{array}$ \\
\hline & $\begin{array}{c}\text { Gelecekte yüz yüze } \\
\text { bakma olasılığ }\end{array}$ & - Van Knippenberg ve Steensma (2003) \\
\hline & Liderlikle ilişkisi & $\begin{array}{ll}\text { - } & \text { Ansari, Aafaqi ve Zainal (2007) } \\
\text { - } & \text { Cable ve Judge (2003) } \\
\text { - } & \text { Krishnan (2004) } \\
\text { - } & \text { Sparrowe, Soetjipto ve Kraimer (2006) } \\
\end{array}$ \\
\hline \multirow{2}{*}{$\begin{array}{l}\text { Taktik seçimi } \\
\text { üzerinde etkili } \\
\text { olan örgüt } \\
\text { özellikleri }\end{array}$} & $\begin{array}{c}\text { Okulun özel ya da } \\
\text { kamuya ait olmasının } \\
\text { etkisi }\end{array}$ & - Aydın ve Pehlivan (2010) \\
\hline & Örgütsel adaletle ilişkisi & - Kuru Çetin ve Çınkır (2014) \\
\hline
\end{tabular}


Bir diğer grup araştırma ise taktik sonuçlarını bağlılık, boyun eğme ve direnme boyutları bağlamında ele almıştır. Bağl1lık, hedef kişinin kendisinden istenenleri içten gelen bir istekle kabul etmesi ve bunları başarıyla gerçekleştirmek için çaba ve kararlılık göstermesi; boyun eğme, hedef kişinin kendisinden istenenleri olabilecek en az çabayla, isteksizce yerine getirmesi; direnme ise hedef kişinin kendisinden istenenlere, tartışma, geciktirme ya da doğrudan itiraz etme şeklinde karşı koymasıdır (Falbe ve Yukl, 1992). Yukl ve Tracey'in (1992) çalışmasına göre ise, istişare, ilham verme ve mantıkla ikna, hem astlara hem üstlere hem de iş arkadaşlarına yönelik uygulandı̆̆ında, göreve bağlanma sonucunu beraberinde getirebilen ve sosyal açıdan kabul edilebilir taktiklerdir. Buna karşılık yine aynı araştırmaya göre baskı uygulama, başkalarıyla birleşme ve meşrulaştırma genellikle etkisiz ve sosyal açıdan istenmeyen; yaranma ve takas ise aşağ 1 doğru uygulandığında kısmen etkili, fakat yukarıya doğru uygulanması durumunda etkisiz taktiklerdir.Yukl, Kim ve Falbe (1996) de bask1 uygulama yerine istişare, ilham verme ve mantıkla ikna taktiklerinin hedefte bağlilık sonucu getirmesinin daha yüksek bir olasılık olduğunu görmüşlerdir.

Bütün bu olası sonuçlar nedeniyle kimi taktikler diğerlerine göre daha fazla tercih edilmektedir. Örneğin Steizel ve Rimbau-Gilabert (2013) sanal ortamlarda, üstlere yönelik olarak en sık kullanılan taktiklerin mantıkla ikna, araya başkasını koyma ve başkalarıyla birleşme olduğunu görmüşlerdir. Taktik tercihine sert/yumuşak kategorileri bağlamında yaklaşan, Van Knippenberg ve diğerleri (1999) ise insanların yumuşak taktiklere, sert taktiklerden daha fazla eğilimli olduklarını, buna karşılık kendilerine adaletsiz muamele edildiğini hissettiklerinde sert taktiklere başvurabildiklerini ortaya koymuşlardır.

İlgili alanyazında taktiklerle ilişkili olarak değinilen bir diğer konu da üstlere yönelik etkileme taktiklerinin siniflandirılması olarak ifade edilebilecek olan etkileme stilleri ya da stratejileridir. Kipnis ve Schmit'in (1988), üstlere yönelik olarak kullanıldığını belirttiği, Farmer ve Maslyn (1999) tarafından test edilip, "yaranmaya çalışan" hariç diğer üç boyutun var olduğunu tespit ettiği dört etkileme taktiği stili şunlardır:

Taktisyen (Tactician). Taktiklere ortalama sıklıkta başvururlar ve mantıkla iknaya daha fazla yönelirler.

Taktik yağdıran (Shotgun). Etkileme taktiklerine en çok bunlar başvururlar ve bu arada dayatmac1lık ve pazarlık etmeye daha fazla yönelirler. başvururlar.

Yaranmaya çalışan (Ingratior). Diğerlerine oranla dostça taktiklere daha çok

Seyirci kalan (Bystander). Üstlerine karş1 etkilemeye pek az başvururlar.

Etkileme taktiklerine ilişkin alanyazında odaklanılan boyutlar, konunun çalışma ortamındaki etkileşimlerde taşıdığı önemi gözler önüne sermektedir. Etkileme taktiklerine eğitim sisteminin yönetilmesi açısından bakıldığında ise, okulların etki altında kalmadan, nesnel bir şekilde denetlenmesi, çalışmaların yasal metinlere uygunluğu ve performansın doğru şekilde tespit edilmesi bakımından önem taşıdığı söylenebilir. Bu durumda okul yöneticilerinin maarif müfettişlerine yönelik etkileme taktiklerinin incelenmesi, denetim sürecinin başarısına önemli katkılar sağlayabilir. Türkiye'de etkileme taktikleri konusunda yapılan araştırmalara bakıldığında, eğitim yönetimi alanında etkileme taktiklerine odaklanan araştırmaların sayıca azlığ 1 (Aydın ve Pehlivan, 2010; Dağlı ve Çalık, 2016; Kuru Çetin ve Çınkır, 2014) ve var olan araştırmaların da etkileme taktiklerini öğretmen-okul müdürü etkileşimi çerçevesinde ele aldığ görülmektedir. Sonuç olarak ne Türkiye'de ne de Türkiye dışında okul yöneticilerinin müfettişlere yönelik etkileme taktiklerine odaklanan herhangi bir araştırma yapılmamıştır. Eğitim yönetimi alanında gerçekleştirilecek böylesi bir araştırma etkileme taktiklerine ilişkin hem ulusal hem de uluslararası alanyazına önemli katkılar sağlayacağı düşünülmektedir. Ayrıca elde edilecek bulgular, müfettişlerin hizmet öncesi ve hizmet içi eğitim programlarında kullanılarak müfettişlerin denetim sürecinde etki altında kalmamaları için bilgilendirilmeleri açısından da faydalı olacaktır. Alanyazının söz konusu eksiğinden yola çıkan bu araştırmanın amacı, maarif müfettişlerinin bakış açısıyla okul yöneticilerinin:

(1) Maarif müfettişlerine yönelik etkileme taktikleri kullanıp kullanmadıklarını,

(2) Kullanıyorlarsa hangi taktikleri kullandıklarını, 
(3) Taktik seçimine belirleyici olan etmenlerin neler olduğunu,

(4) Kullandıkları taktiklerin araştırmaya katılan müfettişler üzerindeki etkilerini ortaya çıkarmaktır.

\section{Yöntem}

Okul yöneticilerinin maarif müfettişlerine yönelik etkileme taktikleri alanyazında daha önce hiç araştırılmamış bir konudur ve bu araştırma söz konusu sosyal fenomene ilişkin bir keşif çalışması niteliğindedir. Araştırmanın keşfetmeye yönelen doğası nedeniyle araştırmacılar nitel araştırma metodolojisi kullanmıştır. Araştırma katılımcıların algılarına dayalı olacak şekilde desenlendiğinden, araştırma verileri yüz yüze, yarı yapılandırılmış görüşmelerle toplanmıştır.

\section{Çalışma Grubu}

$\mathrm{Bu}$ araştırma İç Anadolu bölgesindeki bir ilde görev yapmakta olan dokuz maarif müfettişinin katılımı ile gerçekleştirilmiştir. Araştırma konusuna mümkün olduğunca farklı perspektiflerden bakabilmek için maksimum çeşitlilik örneklemesi yaklaşımı benimsenmiştir. Bu kapsamda sağlanabilen fark alanları kıdem, eğitim düzeyi, cinsiyet ve sendikadır.Söz konusu fark alanları göz önünde bulundurularak araştırma için uygun olduğu düşünülen maarif müfettişlerine davette bulunulmuş, araştırmaya katılmayı kabul eden dokuz müfettiş ile araştırma gerçekleştirilmiştir. Çalışmaya katılmaya gönüllü kadın maarif müfettişi bulunamaması nedeniyle dokuz katılımcının tamamı erkektir. Katılımcılardan dördü Tem-Sen, üçü Eğitim Bir-Sen, biri Türk Eğitim-Sen üyesi iken birinin ise sendika üyeliği bulunmamaktadır. Katılımcılardan yedisi EYTPE lisans eğitimi almıştır ve bunlar arasından altısının aynı alanda yüksek lisans derecesi de vardır. İki katılımcı ise Milli Eğitim Bakanlığı Müfettiş Yetiştirme Kursunu bitirerek göreve başlamıştır. Katılımcıların eğitim denetimi alanındaki deneyimleri on yıldan az düzeyinden başlayarak otuz yıldan fazla düzeyine kadar çeşitlilik göstermektedir. Katılımcıların tamamının maarif müfettişliği görevinden önce öğretmenlik, bazılarının ise ayrıca eğitim yöneticiliği deneyimleri vardır ve tamamı maarif müfettişi olarak birden fazla ilde görev yapmıştır.

$\mathrm{Bu}$ araştırmanın dokuz katılımcısı görev yaptıkları ildeki 65 maarif müfettişinin yaklaşık 1/7'lik bölümünü oluşturmaktadır. Detaylı olarak betimlenmelerinin katılımcıların kimliklerini ortaya çıkaracağı düşüncesiyle katılımcı grubun özelliklerinin tablo halinde tek tek betimlenmesi yerine, genel olarak betimlenmeleri yaklaşımı benimsenmiştir. Bulgular bölümünde doğrudan alıntıların tek bir katılımcıdan gelmediğini göstermek üzere her alıntının sonunda (K1, K2) gibi katılımcının kimliğini ortaya koymayan kodlar kullanılmıştır.

\section{Veri Toplama}

Veri toplama sürecinde araştırmanın yürütüldüğü ilin İl Milli Eğitim Müdürlüğünden araştırma izni alındıktan sonra maarif müfettişleri ile iletişime geçilmiş, ulaşılmaya çalışılan fark alanlarına uygun ve araştırmaya katılmayı kabul eden dokuz katılımcı ile yüz yüze görüşmeler gerçekleştirilmiştir. Görüşmeler öncesinde katılımcılara Creswell (2007) tarafından bir örneği verilen ve araştırmanın içeriği ile katılımcının çekilme/gizlilik haklarını ve karşılaşabilecekleri risk ve rahatsızlıkları açıklayan imzalı tahhüt formu verilmiştir. Görüşmelerin tamamıbirinci araştırmacı tarafından2015 yılı Haziran ayı içerisinde, araştırmacının fakülte binasındaki ofisinde gerçekleştirilmiştir. Bütün görüşmeler dijital ses kayıt cihazı ile kaydedilmiştir. Görüşmelerden en kısası 36 dakika (2899 kelime), en uzunu 104 dakika (9512 kelime) sürmüştür. Dokuz görüşmenin ortalama süresi 70,4 dakikadır. Araştırmacılar daha önceki nitel araştırma deneyimlerinden yola çıkarak, katılımcılara onları görüşmeye hazırlamak amacıyla bir gün önceden görüşme sorularını ve taahhüt formunun bir örneğini göndermiş ve böylelikle katılımcıların araştırma konusuna ilişkin olarak düşüncelerini toparlayarak gelmelerini sağlamaya çalışmışlardır. Görüşmeler sırasında katılımcılara yöneltilen sorular şöyledir:

1. Okulda gerçekleştirdiğiniz denetim sırasında okul yöneticileri size yönelik etkileme taktikleri kullanır mı?

2. (Eğer kullanıyorlarsa) Okul yöneticilerinin ne tür taktiklerini gözlemlediniz?

3. (Eğer kullanıyorlarsa) Taktik seçiminde etkili olan faktörler nelerdir? 

nasildir?

4. (Eğer kullanıyorlarsa)Kullanılan taktiklerin sonuçlarına yönelik değerlendirmeleriniz

Katılımcıların taktilere maruz kalma deneyimleri, son üç soru kapsamında sonda sorularla daha detaylı anlaşılmaya çalışılmıştır.

\section{Verilerin Analizi}

Görüşmelerin tamamlanmasının ardından transkripsiyon sürecine geçilmiş, ses dosyaları görüşmeye katılmayan ikinci araştırmacı tarafından sesi yazıya dönüştüren bir yazılım (Dikte 2.70) kullanılarak kelimesi kelimesine yazıya geçirilmiştir. Böylece görüşmeye katılmayan araştırmacı da görüşme içeriğini detaylı bir şekilde öğrenebilmiştir. $\mathrm{Bu}$ işlemin ardından görüşmeleri gerçekleştiren araştırmacı ses dosyalarını dinleyerek transkripsiyon metinlerini okumuş, böylelikle hem görüşmeleri hatırlamış hem de transkripsiyondaki kimi hataları bularak düzeltmiştir. Verilerin bu şekilde analize uygun hale getirilmesinden sonra transkripsiyonu yapan araştırmacı, NVivo8 yazılımı kullanılarak toplanan verileri açıklayabilecek kavramlara ve ilişkilere ulaşmak için içerik analizi yapmıştır. Ortaya çıkan analiz bulgularını görüşmeleri gerçekleştiren araştırmacının da kontrol etmesiyle araştırmanın iç geçerliği arttırılmaya çalışılmıştır. Katılımcılara bulguların gönderilerek kontrol etmelerinin sağlanması alanyazında geçerliği artırmaya yönelik bir önlem olarak "araştırma katılımcıları tarafindan inceleme" (Patton, 2002, 560) ya da "üye kontrolü" (Sandelowski, 2008, 502) adlariyla anılan bir uygulamadır. Alıntıları da içeren bulguların taslak metni, "Bu metinde doğru bulmadığınız bir ifade var mıdır?" sorusu ile katılımcıların elektronik posta adresine gönderilmiş, böylelikle katılımcılara düzeltme talep etme olanağı sunulmuştur. Düzeltme isteğinde bulunan katılımc1 olmamıştır.

\section{Bulgular}

Okuyucuların bulguların akışını daha rahat takip edebilmeleri için içerik analizi sonucunda ortaya çıkarılan kategorileri yansıtan alt başlıklar Tablo 3'de sunulmuş olup başlıkların doğrudan alıntılarla açıklanmış detayları aşağıdaki gibidir:

\section{Okul Yöneticilerinin Kullandıkları Taktikler ve Bu Taktiklerin Katılımcılar Üzerindeki Etkileri}

Katılımcılara göre, okul yöneticilerinin başvurdukları taktiklerden biri, "müfettişi hoş tutmak"tır. Bu taktik de kendi içerisinde "özenli davranışlarla hoş tutmak" ve "kurnaz davranışlarla hoş tutmak" olmak üzere iki alt taktiğe ayrılabilir. Özenli davranışlarla müfettişi hoş tutmaya çalışan yöneticiler, katılımcılarca protokol kuralları olarak ifade edilen, karşılama, uğurlama ve davranış kurallarına dikkat etme, denetim günü gerekli evrakları önceden hazır etme, giyimine özen gösterme ve denetim grubuna çalışmalarını rahatlıkla yürütebilmeleri için kendi makam odasını tahsis etme gibi özen ve nezaket içeren davranışlar sergilemektedirler. Aşağıdaki alıntı böylesi davranışlara ışık tutmaktadır:

...daha okula gelişinizden itibaren sizi aracınızda karşılayıp, makamında nerede oturacağını bilen okul müdürleri ile karşılaştık. Mesela makamına oturmadan karşınızda oturup [katılımcı okul yöneticisinin misafir koltuklarında oturmasını kastediyor] sizi hoş şekilde ağırlamaya çalışan, karşılamaya çalışan ...

Araştırmacı: Kapıda karşıllyor.

Katılımcı: Aynı şekilde uğurlarken de daha araca kadar uğurlayıp o şekilde kuralları filan, okul müdürleri ile karşılaştım. (K8).

Özenli davranışlarla hoş tutma taktiği katılımcıları olumlu etkilemekte; hem kendilerini önemli hissetmekte hem de müdürün görevlerini yerine getirme yeterliğine sahip olduğunu düşünmektedirler. Müdürlerin bu konularda gerekli özeni göstermemesi, örneğin imkânı olmasına karşın müfettişlere denetim çalışmaları için yeterli bir oda sunmaması ise katılımcıları rahatsız etmektedir. Özenli ve özensiz davranışların etkileri aşağıdaki alıntıda net bir şekilde 
görülmektedir:

Kapıda karşılamak da bir protokol kuralından ziyade, gelen misafirinizi kapıda karşılamak için gelen kişilere karşı, yani ilk başta tamam diyorsunuz ki "Bu okulun müdürü gerçekten misafirlere veya gelen insanlara değer veriyor.” Başta biz etkilendik yani daha sonra işte hazırlıklı oluyor, biz denetimde hangi konulara bakacağımızı gönderiyoruz, söylüyoruz ona göre hazırlıkl oluyor okul müdürleri; bakıyorsunuz evraklar hazır, her şey hazır diyorsunuz ki "Bu gerçekten denetlenmek için hazır." ama bazı okul müdürleri de biraz önce ifade ettiğimiz gibi kllık klyafetine önem göstermiyor, diyorsunuz ki bu okulu müdürü başta sizi de önemsemiyor yani amirlerini de önemsemiyor, denetimi de önemsemiyor insanın aklına şöyle bir şey geliyor: Bunun acaba başka yerden bir şeyi mi var acaba? [Katılımcı, karşısındaki yöneticinin olası ilişki gücünü kastediyor] (K2)

Tablo 3. Bulguların Başlıkları

Okul müdürlerinin kullandıkları taktikler: Okul müdürlerinin kullandıkları taktiklerin müfettişler üzerindeki etkileri:

o Müfettişi hoş tutmak:

- Özenli davranışlarla hoş tutmak

- Kurnaz davranışlarla hoş tutmak

o Kendi başarılarını sergilemek

o Gücünü hissettirmek:

- Müfettişe uzmanlık gücünü hissettirmek

- Müfettişe ilişki gücünü hissettirmek

o Müfettişle ortak noktalar üzerinden yakınlık kurmak
- Müdürü yeterli algılama

- Önemsenme duygusu

- Rahatsızlık duygusu

- Olumlu alg1

- Rahatsızlık duygusu

- Müdürün yetersizliği algisı

- Müdür görevinde başarılıysa ve taktiği aşırı kullanmıyorsa, olumlu alg1

Okul yöneticilerinin etkileme taktikleri seçimlerinde belirleyici olan etmenler:

o Bireysel etmenler:

- Yöneticilik kıdemi

- Cinsiyet

- Kültür

- Sosyal beceri düzeyi

- Yeterlik düzeyi

o Okulun özellikleri

o Müfettişlerin tutumu

Kurnaz davranışlarla müfettişi hoş tutmaya çalışan yöneticiler ise, müfettiş karşısında edilgen ve itaatkâr bir tutum içerisine girmek, müfettişleri aşırıya kaçacak şekilde övmek, siyasi görüşünü öğrendiği müfettişin suyuna gitmek, tanıdıkları vasıtasıyla müfettişin özel işlerine (arabasını tamir ettirmek vb.) yardımcı olmaya çalışmak, cevabını bildiği halde müfettişe rahatlıkla cevap verebileceği sorular sorarak müfettişin kendini iyi hissetmesini sağlamak, müfettişten yardım talep etmek ve etkileme kastıyla yemek ikramında bulunmak gibi davranışlar sergilemektedirler. Ne var ki yemek ikramı konusunda şöyle bir muğlaklık vardır: Kimi katılımcılara göre, özellikle doğu illerinde yemek ikramı, okul yöneticisi tarafindan etkileme taktiğinden çok bir zorunluluk olarak algılanabilmektedir. Nedeni her ne olursa olsun, katılımcılar son dönemlerde çay dışında ikram kabul etmemek gibi bir önlem geliştirmek zorunluluğu hissetmişlerdir ve artık okul yöneticilerinin 1srarla yemek teklifinde bulunmamalarından memnundurlar. Bu taktik kategorisi içerisinde en sık değinilen taktik olan edilgen ve itaatkâr tutum içerisine girmeyi aşağıdaki alıntı örneklemektedir: 
... O andaki durumu kurtarayım, bunlar bir gitsin de sıkıntı yaşamadan durumu kurtarayım. diye her söylediğinize "Evet efendim. Çok doğru. Çok yerinde bir karar." diyen "Bunu hemen yerine getireceğim." hemen o anda müdür yardımcısını çağırıp hemen "Şunu şöyle yapalım." diyen okul müdürleri çok daha fazla. Yani böyle inatlaşan "Kendi doğrularım, benim doğrularım; ben bunları yapmak durumundayım. Siz ne derseniz deyin ben bunu yaparım." diyen okul müdüründen ziyade "Evet efendim. Bu söylediğiniz yerinde ve doğru hemen uygulamaya geçelim" diyen okulu müdürü ... (K3).

Edilgen ve itaatkâr tutum sergileme ya da abartılı övgülerde bulunma gibi davranışlarla kendini gösteren kurnaz davranışlarla hoş tutma davranışı, katılımcıların kendilerini rahatsız hissetmelerine neden olmakta ve amaçlanan etkinin tam tersini yapmaktadır. Diğer taraftan katılımcılar, kendileri için değilse de kimi müfettişlerin böylesi davranışlardan memnun kalma olasılığının olduğunu da dile getirmişlerdir. İçerik analizi sürecinde kurnazca davranışlarla etkilemenin kapsamına alınan müfettişten yardım isteme ve müfettişten faydalandığını dile getirme gibi davranışlar, eğer yapmacık görünmüyorsa, katılımcılarda görevlerini başarıyla yerine getirdikleri duygusuna neden olmakta ve bu nedenle de olumlu karşılanmaktadır. Sonuç olarak, kurnaz davranışlarla etkileme taktiği de abartıl1/yapmacık görünmemek koşuluyla hedefine ulaşabilmektedir. Aşağıdaki iki alıntı, iki ayrı kurnaz davranışla hoş tutma girişiminin, aynı müfettiş üzerindeki farklı etkilerini ortaya koymaktadır:

[katılımcı yardım isteme taktiğinden bahsediyor] ... kendimden şey yaparak söyleyeyim: Bunlar müdürün etkilendiği, yardım alabildiği için teşekkür ettiği ve [Müfettişin yöneticiye yönelik] etkileme çabasının olumlu sonuç yarattığl, okul için ya da iş için olumlu sonuç yarattı̆̆ imajı, inancı müfettişte oluşursa, müfettişsin de işine daha çok motive olarak çalıştığını söylenebilir. Bu okuldaki çalışma süreci içerisinde "Ya benim bu sözümden lafi anladl, dinledi anladl; yanlıșını gördü ben de yararlı oldum; o da onu anladı" anlamında bir algl, bir imaj söz konusuysa, müfettişin de orada ondan sonraki çalışma sürecinde daha motive olduğu ve yararlı olmaya dönük çaba sarf ettiğ söylenebilir. (K6)

... demin bahsettik ya etkileme ihtiyacı hissettiği için edilgen oluyor ... Ben geçen gün size de söylemiştim, hafta sonu bir başka görev için okulda bulunduğumda, denetimle teftişle ilişskili olmasa bile edilgen bir şekilde sürekli gözüme ve ağzıma bakan bir tavrı vardı müdürün; ben rahatsı oldum. Ben ne istiyorum, ne yapmak istiyorum, ne yapacă̆ım hep benden bir şeyler bekleyen, komutlar bekleyen bir hali vardı... (K6)

Katılımcılara göre okul yöneticilerinin sıkça başvurdukları diğer bir taktik ise kendi başarılarını sergilemektir. Yöneticinin okula geldiği günden bu yana ortaya koyduğu başarılı işleri henüz kendisine sorulmadan ya da bir başarısızlığı ortaya çıktığında müfettişlerin dikkatini dağıtmak için sergilemeye başlamasıyla çok sık karşılaşılmaktadır. Bu taktikle karşılaşan katılımcılar, okula henüz atanmış yöneticilerin, okullarının kapasitelerinin üzerinde iddialı projelere giriştiklerini de gözlemlemişlerdir. Bunun yanı sıra, yüksek lisans yapan okul yöneticilerinin aldıkları eğitime konuşmalarının akışı içerisinde değindikleri de görülmektedir. $\mathrm{Bu}$ kategori içerisinde her katılımcının değindiği "kendi başarılarını sergilemek" taktiği şöyle örneklendirilebilir:

Bir de şu var, bazen çok çalışkan, çok gayretli okul yöneticileri var; bunlar kendilerini bir şekilde size takdim etmek, yani yaptı̆̆ şeyleri takdim ederek takdir edilmesini istiyor. Bunun üzerine de yapılan çalışmaların, daha sonra yapılan denetim çalışmalarının iyi bir sunumdan, iyi bir görüntüden sonra başlanıldiğı takdirde ...güzel şeylerin olacă̆ı bakış açısının, tavrının, tutumunun olduğunu seziyoruz. Yani önce yapılan güzel şeyleri göstermek, bunun etkisinde kalınarak diğer eksik olabilecek 
şeylerin, yanlış olabilecek şeylerin, daha rahat tolore edici bir hale getirilmesi (K1).

Okul yöneticisinin kendi başarılarını sergilemesi -bu davranışı, başarısızlığının ortaya çıktığı boyutlarda dikkat dağıtmak amacıyla sergilememesi koşuluyla- katılımcılar tarafından olumlu karşılanmaktadır. Hatta okul yöneticisinin lisansüstü eğitimini dile getirmesi, kitaplığındaki eğitime ilişkin kaynakları vurgulaması ya da başka yollardan kişisel başarılarını acemice ortaya koymaya çabalarını bile katılımcılar hoşgörüyle karşılamakta ve okul yöneticisini böylesi çabalarının devamı için motive ettiklerini belirtmektedirler. Söz konusu olumlu karşılama ve motive etme eğilimi aşağıdaki alıntıda net bir şekilde görülebilir:

... denetime başladı̆̆ımızda "Hocam ben de eğitim fakültesinin falanca bölümünde yüksek lisansımı yaptım." diyerek başlayan yöneticilerimiz oldu. Biz onu iyi niyetle değerlendirdik, biz de teşvik ettik, "Aferin, keşke doktoranı da yapsan, daha büyük hizmetlerde bulunursun." diye. Mesela bir ögretmen kendi konularlyla ilgili üç tane makale, iki tane kitap okur ama yüksek lisans yapan bir ögretmen onlarca makale, onlarca kitap okur, bir emek verir. Teşvikimiz oldu yani o yönüyle. (K5)

Katılımcılarca dile getirilen bir diğer taktik kategorisi ise, okul yöneticilerinin sahip oldukları gücü ima ederek müfettişi etkilemekte kullandıkları taktikleri kapsamaktadır. "Gücünü hissettirmek" olarak adlandırılan bu kategoriyi, müfettişe uzmanlık gücünü hissettirmek ve müfettişe ilişki gücünü hissettirmek şeklinde ikiye ayırmak mümkündür.

Müfettişe uzmanlı gücünü hissettirmek. Çok kıdemli okul yöneticilerinin göreve yeni başlamış, genç müfettişe mevzuat alanındaki yeterliğini ve engin deneyimini hissettirmesi, müfettişlerin kariyerlerinin ilk yıllarında karşılaşabildikleri bir taktiktir. Ne var ki böylesi bir taktikle deneyimli müfettişler de karşılaşabilirler. Şöyle ki 2014 yılında ilköğretim ve bakanlık müfettişlikleri "Maarif Müfettişliği" adı altında birleştirilmiş ve daha önce ilköğretim okullarını denetim yapan müfettişler, liseleri de denetlemeye başlamışlardır. $\mathrm{Bu}$ yeni düzenlemenin sonucunda, lise yöneticisinin detaylarıyla bildiği bir konuya kasitlı olarak müfettişi çekerek, ona kendi bilgi düzeyini hissettirmeye çalışması, müfettişin ortaöğretime yabancı olduğunu ima etmesi, hatta nadir de olsa açık açık müfettişe ortaöğretim mevzuatına ilişkin bilgi düzeyinin yetersiz olduğunu ifade etmesi şeklinde yeni bir taktik ortaya çıkmıştır. Bu taktiğe müfettişlerin tepkisi ise, lise denetimlerine detaylı ön çalışmalar yaparak gitmek şeklinde olmuştur. $\mathrm{Bu}$ durumu aşağıdaki alıntı örneklemektedir:

... bazen şöyle bir şey de var, az önce benim söylemek istediğim şey, bazı müdürler yüzde yüz emin olduğu bir noktayla ilgili bir soru soruyor ... "Hocam şöyle bir durum vardl, bu konuda nasıl yapmamı gerekiyor?" falan diye ondan sonra "Şöyle şöyle yapacaksın." diyorsun "Hocam yalnız şöyle yaptık biz, acaba doğru mu değil mi? Mevzuatta da böyle bir şey var." filan, işte "Orta öğretim kurumlar yönetmeliğinde şöyle yaptık.” falan. Yüzde yüz iyi bildiği alana çekerek müfettişi, eğer müfettiş şeyse, o noktada müdürün dümen suyuna ya da dalga şeyine giriyorsa, bu sefer o konuda sana ders vermeye başllyor müdür. (K7)

Uzmanlık gücünü hissettirme taktiğinin başarılılarını sergilemek kategorisi içerisinde geçen "aldığg eğitime değinmek"ten fark1, meydan okuyucu ve üstünlük taslayan bir tonunun olmasıdır. Bir katılımcının söz konusu meydan okuma karşısındaki rahatsızlığı aşağıdaki alıntıda kendisini hissettirmektedir:

... sen gevelersen işte ilkokulda falan falan dersen veya efendime söyleyeyim yani gevelersen, sen orada ona teslim olmuşsun. Branşımızla şey yapmaya çalışıyor, etkilemeye çalışıyor, yani "Sen bu işi bilmezsin; sen ilkokul ögretmeni kökenlisin." Tamam mı? "Sen bu işe vaklf değilsin." Ama arkadaş ben eğitim yönetimi bölümü mezunuyum, otuz senedir de bu işi yapıyorum. Ha bunu deme gereği de duymazsın o da 
sana kalmış bir şey (K9).

Müfettişe ilişsk gücünü hissettirmek. Okul yöneticisinin hükümete yakınlığg ile bilinen, etkili bir sendika ile yakın ilişkilerini ima etmesi, katılımcıların tamama yakınının algıladıkları bir taktiktir. Yine bu kategori içerisinde, okul yöneticisinin etkili siyasilerle veya üstleriyle yakın ilişkilerine değinmeleri de müfettişleri etkilemek için başvurdukları bir taktik olarak görülmektedir. Bu taktik grubu bir katılımcının kelimeleriyle şöyle hissedilmektedir:

Etkileme taktiğinden birisi mesela, kullandikları, "Beni buraya getirenleri mahcup etmeyeceğim." diyerek baskı unsurlarının arkasında olduğunu ima etmeye çalışan tiplerle, okul müdürü tipleriyle de karşılaştım. (K3)

Aşağıdaki alıntıda da görülebileceği gibi, okul yöneticisinin ilişki gücünü hissettirmeye çalışması olumlu sonuçlar vermemekte, müdürün yetersizliği algısına neden olmaktadır. Taktik belki de bu nedenle doğrudan söze dökmek yerine ima etme şeklinde ortaya çıkmaktadır:

... Okul müdürlerinin bu tip davranışları var. Özellikle son yıllarda iktidara yakın sendika mensubu idarecilerin, sendikalı olduklartn belirten, ima eden ifadeleri ya da bunları davranışlarında hissettirmeye çalıştıkları aşikâr. Bu bizde olumlu bir etki yaratıyor mu? Olumlu bir etki yaratmiyor; bilakis böyle bir davranışı, böyle bir şey hissettirmesi onun müdürlük noktasinda yeterliliği ya da belirli bir yerlere dayanma noktasında şey olarak değerlendiriyorum ben, müfettiş olarak, idarecilik noktasındaki bir acziyeti olarak değerlendiriyorum. (K7)

Katılımcıların özellikle denetim sürecinin ilk saatlerinde, tanışma evresinde sıkça karşılaştıkları bir taktik ise okul yöneticisinin olumlu bir hava yaratmak için müfettişlerle yakınlık kurabileceği ortak noktaları kullanmasıdır. Bu kategori içerisinde en sık dile getirilen ortak nokta, müfettişin memleketinin kullanılmasıdır. Okul yöneticilerinin yakınlık kurmak üzere odaklandıkları diğer alanlar arasında, müfettişin müfettiş olan ve olmayan arkadaşları, branşı, dini inançları, siyasi görüşü, sendikası, hobileri sayılabilir. İşi daha da ileri götüren kimi okul yöneticilerinin, denetim grubu hakkında denetim öncesinde bilgi topladıkları da katılımcılarca bilinmektedir. Bu taktiği, bir katılımcı şu şekilde betimlemektedir:

... özellikle ilk olarak en çok kullanılan taktik şu: "Hocam nerelisiniz, nerede okudunuz, buralı misinız, ne zaman geldiniz buraya?” Bizim Türk toplumunun genel bir özelliğidir ya hemşerilik veya oraya yakın olmak. Ben yine söyledikten sonra o mutlaka ille kendi ile bir iliş̧ilendirme yoluna gidiyor; ya bir okul arkadaşı vardır efendime söyleyeyim ya askerliğini orada yapmıştır, komşusu vardır, ögretmeni vardır, işte ilk görev yerim ... şey yapıyor yani işi görüyor sen de cevap veriyorsun, vermek zorundasin ...işte belirli bir nerelisin muhabbetinden sonra baklyorsun yavaş yavaş o seni tartmaya çalışlyor, yani biraz sana yakınsa o mesajı vermeye çalışıyor, sözleriyle aynı siyasi görüşten veya ayn sendikadan olduğunu hissettirmeye çalışıyor. Hangi siyasi görüşsten veya hangi sendikadansa ne yapıyor bu sefer, ortak tanıdıklarımızdan bahsediyor, diyor ki "Falancayı tanıyormuşsun hocam, işte o da şöyle şöyle oğlunu evlendirdi" veya "Falan ögretmenimiz, okul müdürümüz”. Açık açık şu sendikadanım demiyor, hissettirmeye çallşıyor ...diyor ki "Hocam duydunuz mu, falan sendika başkanımız da hastaymış?" Sen orada yani mesajı allyorsun bu bana bir şey veriyor mesaj veriyor tamam mı? (K9)

Ortak noktalar üzerinden yakınlık kurma taktiği, taktik aşırı derecede kullanılmadığı ve okul yöneticileri müfettişler tarafından başarılı bulunduğu durumlarda olumlu duygulara neden olmaktadır. Bu nedenle, okul yöneticilerinin iletişim/yakınlık kurabilmek için müfettişle ortak noktalara odaklanmaları, eğer yöneticinin müfettişleri rahatsız eden bir hatası/eksikliği de yoksa isabetli bir tercih olabilir. Bu taktiğin olası sonuçlarına bir katılımcının şu ifadeleri örnek 
verilebilir:

Ortalama bir performansı varsa bu hemşericilik işin gülü çiçeği oluyor yani. Genelde, müfettişlerimize haksızlı yapmayalım, genel şeyi söyleyeyim, etkilenmediğimizi söyleyemeyiz, etkileniyoruz ama bütün etkenlere rağmen kişinin ortaya iyi bir yöneticilik sergilemesi ön koşuldur diyebilirim (K8).

\section{Okul Yöneticilerinin Etkileme Taktikleri Seçimlerinde Belirleyici Olan Etmenler}

Okul yöneticilerinin maarif müfettişlerini etkilemeye yönelik taktik seçimlerinde okul yöneticisinin bireysel özellikleri, okulun özellikleri ve müfettişlerin tutumu belirleyici olmaktadır. Katılımcılara göre okul yöneticisinin taktik seçiminde belirleyici olan bireysel özellikleri, yöneticilikteki kıdemi, cinsiyeti, sosyal beceri düzeyi ve yeterlik düzeyidir. Bu özellikleri biraz daha açmak gerekirse, yaşça büyük olan okul yöneticilerinin etkileme taktiklerine kolayca başvurmasına karşın, yöneticiliğe yeni başlamış, genç yöneticilerin taktik kullanma konusunda çekingen davrandıkları sıkça dile getirilmiştir. Araştırmanın katılımcıları, kadın yöneticilerin sayıca az olmaları nedeniyle cinsiyetin taktik seçimi üzerindeki etkisine ilişkin net değerlendirmeler yapamazken sadece bir katılımc1, kadın yöneticilerin okulun temizliğine dikkat çekmeye çalıştıkları gözlemini paylaşmıştır. Yine bu bağlamda, katılımcılar erkek okul yöneticilerinin kadın mevkidaşlarına oranla taktik kullanımına daha eğilimli olduklarından söz etmişlerdir. Çok net teşhislerle olmasa bile, okul yöneticisinin doğup büyüdüğü şehrin kültürünün de ("Trabzon'da daha doğrudan", "Adıyaman'da daha içten” gibi ifadelerle) taktiğe başvurma düzeyi üzerinde etkisi olduğu katılımcılarca dile getirilmiştir. Bunlar kadar s1k dile getirilmemekle birlikte, sosyal beceri düzeyi yüksek olan okul yöneticilerinin taktik kullanımında daha başarılı oldukları ve yönetim sürecinde yetersiz kalan yöneticilerin bu sorunu taktiklere başvurarak aşmaya çalıştıkları da birer katılımcı tarafından dile getirilmiştir. "Taktik seçimlerinde belirleyici olan etmenler" kategorisi içerisinde en sik dile getirilen yöneticilik kıdemi etmenine bir katılımcı şöyle değinmiştir:

...Var tabii canım. Gençler çekiniyorlar, ürkekler, acaba nasıl bir tepkiyle karşılaşırım diye deneyimleri olmadığı için. ... yaş̧lılar deneyime sahiplerse daha rahat kullanıyorlar yani.

Araştırmacl: Neler oluyor mesela?

Rahat size teklifte bulunuyor ve rahat önerilerde bulunabiliyor sizi etkileyebilecek. Daha önce bahsettiğim konular kapsamında dahi konuşabiliyor. "Sizi eve birakayım hocam." diyor, "Nereye gideceksiniz arabayla bırakayım." diyor rahatlikla. Buna genç cesaret edemiyor. Illginç bir şey, gençler söyleyemiyorlar. Uyanık birisiyse oluyor da çok çekiniyorlar. Adam bize çay vermedi ya üç saat boyunca! "Hocam korktum ben çay ikram etmeye." diyor. (K8)

Okul yöneticisinin taktik kullanma düzeyi ve seçimi üzerinde etkili olan bir diğer etmen ise, yöneticisi olunan okulun özellikleridir. Katılımcılara göre şehir merkezinden uzak yerleşim yerlerindeki küçük okullarda yöneticilik çok da arzulanan bir pozisyon değildir ve bunun sonucunda, böylesi okulların yöneticileri şehir merkezindeki büyük ve prestijli okulların yöneticilerine oranla daha içten davranabilmekte ve taktik kullanacak olurlarsa, imkânsızlıklarını ya da tecrübesizliklerini dile getirmeyi tercih etmektedirler. Buna karşılık yine katılımcılara göre, yöneticilik makamının büyük bir prestij sağladığı, şehir merkezindeki büyük okulların yöneticileri yöneticilikte kıdemlidirler ve kendilerine ilişki gücü sağlayan bağlantılara sahiptirler. Bunun sonucunda müfettişler karşısında hatalarını kabul etmeme, resmi davranma ve statüsünü vurgulama davranışları sergileyebilmektedirler. Aşağıda iki katılımcının bu konuya ilişkin düşünceleri, sözü edilen iki ayrı koşulun yöneticilerin taktik kullanma eğilimini nasıl etkilediğine 1şık tutmaktadır: 
vardır ki okullarımızda, valinin odasindan böyle daha lüks tefrişatla donatan okul müdürleri, kendi idari bölümünü kırmızı halılarla donatan okul müdürü tipleri de var. Böyle olunca o zaten orada şeyi veriyor, kuruma girerken, idari bölüme giderken "Burast hakikaten böyle sıradan bir okul değil; ben de stradan bir okul müdürü değilim." imajını vermeye çalışan okul müdürleri vardı ama son dönemde onlar da [Rotasyon uygulaması sonucunda kısa süre önce göreve başlamış yöneticileri kastediyor] belki de koltuktaki o tedirginliğinden dolayı kendisinin bulunduğu okulun, gelmiş olduğu okulun çevre etkisi, okulun büyüklüğünün vermiş olduğu etkiyi tam kestiremedig̈inden dolayı çok onu hissettirmeye çalışan okul müdürüne rastlamadım ama öncekilerden özelliklede aynı kurumda uzun süre kalmış olduğunu ve okulun büyüklügüunden kaynakl olarak "Ben buranın en büyüğüyüm, öyle bir şey ki ildeki şu yöneticiden daha büyügüm." diyen, haliyle davranışlyla bunu hissettiren okul müdürlerini biz gördük; sizler de buna şahit olmuşsunuzdur müfettişliğinizde. (K3)

... zaten köy-kasabadakiler inan çok da atlamıyorlar idareciliğe; yani bir şekilde görev veriliyor, onu götürmeye çalışlyorlar. Çok daraldiğı zaman da "Hocam gerekirse bırakırım ben.” diyor. Üzerine fazla şey yaptı̆̆ zaman veya tespitleri ortaya koyduğun zaman, masaya yatırdığınız zaman çoğu da şunu söylüyor: "Benim tecrübem yok." (K4)

K3'ün merkezdeki, büyük ve prestijli okulların yöneticilerinden bahsederken rotasyon öncesi, uzun süredir aynı okulda görev yapan yöneticiler ve rotasyondan sonra okula henüz atanmış, çekingenlik göstermekte olan yöneticiler olmak üzere iki ayrı yönetici tipinden bahsettiği görülmektedir. Başka katılımcılar da 2014 senesinde gerçekleştirilen okul yöneticilerine yönelik rotasyon uygulamasının, yöneticilerinin etkileme taktiği kullanma düzeyini etkilediğini ifade etmişlerdir.

Son olarak, karşısına çıkan müfettişin sergilediği tutum da okul yöneticisinin taktik kullanımında belirleyici olmaktadır. İletişimin samimi bir havada devam etmesi ve müfettişin katı bir tutum sergilememesi, okul müdürüne etkileme taktiklerine başvurması için cesaret verebilmektedir. Müfettişin tutumunun okul yöneticisinin sonraki davranışlarını nasıl şekillendirdiği K9'un şu ifadesinden anlaşılabilmektedir:

... müdürü açıyor o konuyu, ortaya bir zarf atıyor tamam mı, zarfı denetim elemanı açıp okumaya başlarsa tamam; o muhabbet o ilişsi devam ediyor, tamam mı? Bitiyor. Ama denetim elemanı ölçüsü dâhilinde bu atılan zarfi okumayıp da kısa ve net cevaplarla önünü keserse, okul müdürü de ona göre tavrını belirliyor. Diyor ki "Bu iş olmayacak" yani. (K9)

\section{Tartışma / Sonuç ve Öneriler}

İçerik analiziyle ulaşılan bulgular, katılımcıların okul yöneticilerinin kullandıkları etkileme taktiklerine ilişkin benzer algılarının olduğuna işaret etmektedir. Söz konusu taktikler alanyazında ortaya konmuş olan, farklı mesleklerde görülen etkileme taktikleriyle de bir dereceye kadar benzerlik göstermektedir. Örnek vermek gerekirse, bütün katılımcılarca dile getirilen ve bu araştırmada "müfettişi hoş tutmak" olarak adlandırılan taktik, alanyazında "yaranma" olarak geçen taktikle örtüşmektedir. Bu araştırmada "müfettişle ortak noktalar üzerinden yakınlık kurmak" olarak adlandırılan diğer bir taktik de etkilemeye çalışanın aynı şehirden ya da sendikadan olmak gibi niteliklerini vurgulayarak hedef kişiye yaranma çabasından kaynağını alması nedeniyle yine "yaranma" taktiği ile benzerlik göstermektedir. Her ne kadar Yukl ve Tracey (1992) yaranma taktiğinin üstleri etkilemede yeterli olmadığg ifade etse de diğer iki araştırma (Judge ve Bretz, 1994; Higgins, Judge ve Ferris, 2003) yaranma olarak adlandırılabilecek bu taktiğin üstler karşısında doğru bir seçim olabileceğini göstermektedir. Okul yöneticisi ve müfettiş etkileşimine odaklanan bu araştırmanın bulguları da etkilemeye çalışanın edilgen ve itaatkâr tutum sergileme ya da abartılı övgülerde bulunma gibi davranışlar göstermedikçe, "müfettişi hoş tutmak" taktiğiyle hedefini bir dereceye kadar etkileyebileceğini 
ortaya koymaktadır.

$\mathrm{Bu}$ araştırmada "kendi başarılarını sergilemek" olarak adlandırılan ve okul yöneticisinin başarılı çalışmalarına ilişkin detaylı bilgiler vererek, bulunduğu yöneticilik pozisyonun gereklerini yerine getirdiğine müfettişi inandırmaya yönelik çabaları, alanyazında birden fazla çalışma içerisinde "mantıkla ikna" olarak geçen taktikle benzerlik göstermektedir. Şöyle ki mantıkla ikna taktiği etkilemeye çalışan kişinin hedef kişiyi etkilemek için verilere dayalı mantıklı bir argüman geliştirmesini kapsar; okul yöneticisinin olumlu bir değerlendirme raporu alabilmek için başarılarını vurgulaması da -her ne kadar başarıyı veri olarak ortaya koymanın ötesinde detaylı bir argüman geliştirmeyi kapsamasa da- yine de mantık kullanmayı içeren bir hamledir ve mantıkla iknanın kapsamına girebilir. Alshenaifi ve Clarke'ın (2014) meta-analiz çalışması, mantıkla ikna taktiğinin olumlu sonuç verdiğini göstermektedir. Okul yöneticilerinin taktik kullanımına odaklanan bu araştırmanın verileri de okul yöneticisinin bu davranışının katılımcılar tarafından -başarısızlığının ortaya çıktığı boyutlarda dikkat dağıtmak amacıyla sergilememesi koşuluyla- olumlu karşılandığını göstermektedir. Aynı taktik sadece Üstlere Yönelik Etkileme Stratejileri Ölçeği (Ralston vd., 1993) içerisinde geçen ve "kişinin kendisini örgütün bütün üyelerine, ama en çok da üstlerine karşı aktif bir şekilde olumlu şekilde sunması" (s. 169) olarak tanımlanan "imaj yönetimi" taktiğiyle de uyuşmaktadır.

$\mathrm{Bu}$ araştırmada "gücünü hissettirmek" olarak geçen taktiğin, ilk bakışta etkilemeye çalışanın isteklerini kabul ettirebilmek için ceza ya da ceza tehditlerine başvurmasını kapsayan "yaptırım" taktiğine benzese de aslında, okul yöneticisinin sadece uzmanlık ya da ilişki gücünü ima etmesi, hissettirmesi şeklinde gözlemlendiğinden, alanyazında tam olarak görülmeyen yeni bir taktik olarak ortaya çıktığı anlaşılmaktadır. Bu araştırmanın uzun yıllara yayılan müfettişlik deneyimine sahip katılımcıları dahi okul yöneticilerinin açıkça saygısızlıkta bulunma ya da tehdit etme gibi bir davranışından bahsetmemiştir. Oysa alanyazında geçen "yaptırım" taktiği böylesi davranışları da içerebilir. Yine de "gücünü hissettirme" taktiğinin katılımcılarda okul yöneticisine ilişkin (okul yöneticisinin bulunduğu pozisyona uygun olmadığı şeklinde) olumsuz bir algı oluşmasına neden olduğu açıkça görülebilmektedir.

Gücünü hissettirme taktiğinin hemen ardından, katılımcıların okul yöneticilerinin güç kaynağına ilişkin algılarına 1şık tutan bulgulara da değinmek yerinde olacaktır. Her ne kadar üstün asta yönelik etkileme taktiklerine odaklanmış olsa da Somech ve Drach-Zahavy (2002) etkilemeye çalışan kişinin ve hedef kişinin sahip oldukları gücün taktik seçimi üzerinde belirleyici olduğunu göstermektedir. Bu araştırmanın katılımcıları da yöneticilik makamının büyük bir prestij sağladığı şehir merkezindeki büyük okulların yöneticilerinin kendilerine ilişki gücü sağlayan bağlantılara sahip olduklarını, bunun sonucunda da müfettişler karşısında hatalarını kabul etmeme, resmi davranma ve statüsünü vurgulama davranışları sergileyebildiklerini ifade etmişlerdir. İki araştırmanın bulguları bir arada ele alındığında, etkileme taktiklerinin karşılıklı güç dengeleri bağlamında şekillenmesi olasılığı güç kazanmaktadir.

$\mathrm{Bu}$ araştırmanın verileri okul yöneticilerinin bireysel özelliklerinin de taktik seçiminde etkili olabileceğine işaret etmektedir. Katılımcıların bu konudaki gözlemleri ilgili alanyazınla benzerlik ve farklılıklar göstermektedir. Bireysel özelliklere odaklanan araştırmalara bakıldığında, cinsiyetin taktik kullanımına etkisinin daha önceki araştırmalarda da ele alındığ görülmektedir. Van Knippenberg ve Steensma, (2003), bu araştırmada da ifade edildiği üzere erkeklerin kadınlara oranla etkileme taktiği kullanmaya daha eğilimli oldukları sonucuna ulaşmış, Aydın ve Pehlivan (2010) ise kadın okul yöneticilerin erkek mevkidaşlarına oranla öğretmenleri etkilemeye çalışırken koalisyon taktiğine daha eğilimli olduklarını ortaya koymuştur. Diğer taraftan Kuru Çetin ve Çınkır (2014) ve Akhtar ve Mahmood (2009) ise cinsiyetin etkileme taktiği kullanımları üzerinde belirleyici olmadığını görmüşlerdir. Yukarıda sayılan araştırmaların hiç biri taktik kullanımı konusunu okul yöneticisi-müfettiş etkileşimi bağlamında ele almamıştır ve bu araştırmanın bulguları cinsiyetin bu etkileşimdeki taktik kullanımı üzerinde belirleyici olabileceğine işaret etmektedir. $\mathrm{Ne}$ var ki kadın okul yöneticilerinin sayıca az olması sonucunda, katılımcıların bu konudaki algılarını az sayıda gözlemle oluşturdukları da unutulmamalıdır. 
Yaşın taktik kullanımı üzerinde etkili olduğu daha önceki iki araştırmada da ortaya konmuştur. Akhtar ve Mahmood (2009), gençlerin taktik kullanımının daha fazla olduğunu, Ralston ve diğerleri (2005) ise genç yöneticilerin etkileme davranışlarını yaşlı yöneticilere oranla daha kabul edilebilir bulduklarını göstermişlerdir. Diğer taraftan araştırmamızın bulguları, katılımcıların yaşın taktik kullanımını arttırdığını ifade etmeleri nedeniyle söz konusu iki araştırmanın bulgularından farklılaşmaktadır. $\mathrm{Bu}$ durumun olası nedenleri arasında katılımcıların anlatımlarına konu olan okul yöneticilerinin kültür ve meslek değerlerinin diğer iki araştırmadaki kültür ve meslek değerlerinden farklı olması sayılabilir.

$\mathrm{Bu}$ araştırma içerisinde Tablo 2'de görülebilen, kültürün taktik kullanımı üzerindeki etkilerine odaklanan araştırmalar, kültür kavramını ülkeler arasında karşılaştırmalar düzeyinde ele almaktadır. $\mathrm{Bu}$ araştırmanın katılımcıları ise karşılaştırmaları kendi ülkeleri içerisindeki coğrafi bölgeler arasında yapmakta ve çok net gözlemler ortaya koyamamaktadırlar. Diğer taraftan yine katılımcıların ifadeleri, bölgeler arasında etkileme davranışları bakımından farklılıkların olması olasılığına işaret etmektedir. Etkileme taktikleri konusunda geliştirilecek ölçeklerle yapılacak nicel araştırmalar bölgeler arasındaki farklılıklara ilişkin net ölçümlerle mevcut bilgi birikimine önemli katkılar sağlayabilir.

$\mathrm{Bu}$ araştırmanın bulgularından yola çıkarak bir uygulama önerisi de geliştirilebilir: Müfettişlerin hizmet öncesi eğitimlerinde etkileme taktikleri konusunda bilgilendirilmeleri, deneyimli okul yöneticilerinin karşısında nesnellikten uzaklaşarak hatalı değerlendirmelerde bulunma olasılıklarını azaltacaktır. Böylesi bir eğitimin içeriğinin oluşturulabilmesi için, ülkemiz koşullarında ve okul yöneticisi-müfettiş etkileşimi özelinde daha fazla araştırma yapılması gerekli görünmektedir.

Son olarak bu araştırmanın birkaç sınırlılığına ve bu sınırlılıklara dayalı olarak geliştirilen araştırma önerilerine değinmek yerinde olacaktır. Creswell (2003) "Arka bahçe araştırması" olarak tanımladığ 1 , araştırmacının kendi iş ortamında, iş arkadaşlarıyla gerçekleştirdiği araştırmaların beraberinde getirdiği risklere karşı uyarılarda bulunmuş ve böylesi araştırmalarda geçerlik için önlemler alınmasını tavsiye etmiştir. Bu araştırmada görüşmeleri gerçekleştiren birinci araştırmac1 geçmiş yıllarda müfettiş olarak görev yapmıştır ve katılımcılardan üçü ile müfettişlik yaptığı dönemden başlayan arkadaşlığı vardır. Bu duruma iki açıdan bakılabilir: Öncelikle bu durum -her ne kadar araştırmacı araştırmanın gerçekleştirildiği dönemde katılımcılarla iş arkadaşı olmasa da- bir sınırlılıktır. Çünkü katılımcıların müfettişlik deneyimi olmayan bir araştırmacı karşısında neler söyleyecekleri bilinmemektedir. Diğer taraftan, söz konusu araştırmacının 12 yıl müfettişlik deneyiminin olması da odaklanılan sosyal fenomene aşina olması sayesinde görüşme sürecini daha etkin bir şekilde yürütebilmesini sağlamış ve daha da önemlisi, katılımcıların görüşme sırasında kendilerinden biri olarak gördükleri (kimi katılımcılar bu algılarını görüşme sırasında açıç̧a dile getirmişlerdir) araştırmacı karşısında kendilerini rahat hissetmeleri sonucunu da beraberinde getirmiştir.

Araştırmanın katılımcı sayısı ve katılımcıların çeşitlendirildikleri fark alanları da sinırlılıklar başlığı altında ele alınmalıdır. Katılımcı grubu toplamda 9 müfettişle sinırlıdır ve katılımcıların tamamı aynı ilde görev yapmaktadırlar. Gelecek araştırmaların farklı illerde uzun süre görev yapmış olan, daha fazla sayıda katılımcı ile gerçekleştirilmesi okul yöneticilerinin etkileme taktiklerine ilişkin daha geniş bilgi birikimine ulaşılmasını sağlayabilir.

Araştırmanın bir diğer sınırlılığı ise katılımcıların sadece maarif müfettişlerinden oluşmasıdır. Gelecekteki araştırmalarda maarif müfettişlerinin yanı sıra okul yöneticilerinin de araştırmaya dâhil edilmesi -varsa- müfettişlerin fark edemedikleri başka etkileme taktiklerinin ortaya çıkarılmasını sağlayabilir.

\section{Kaynaklar}

Ansari, M., Aafaqi, R., \& Zainal, S. (2007). Supervisory behaviour and upward influence tactics: The impact of gender. Paper presented at the twenty second annual meeting of the Society for Industrial \& Organizational Psychology (SIOP), New York.

Akhtar, S., \& Mahmood, Z. (2009). A tri-prong variable analysis of influence strategies. World Applied Sciences Journal, 7(9), 1080-1089. 
Alshenaifi, N., \& Clarke, N. (2014). Follower upward influence tactics-key findings from the literature. 06.06.2015 tarihinde http://www.ufhrd.co.uk/wordpress/wpcontent/uploads /2014/11/Najla-Alshenaifi.pdf adresinden erişilmiştir.

Aydin, İ., \& Pehlivan, Z. (2010). Strategies and personality types used by primary school principals in Turkey to influence teachers (Ankara case). Procedia-Socialand Behavioral Sciences, 2(2), 3652-3659.

Cable, D.M., \&Judge, T. A. (2003). Managers' upward influence tactic strategies: The role of managerpersonalityandsupervisorleadershipstyle. Journal of Organizational Behavior, 24(2), 197-214.

Castro, S.L., Douglas, C., Hochwarter, W.A., Ferris, G.R., \& Frink, D.D. (2003). The effects of positive affect and gender on the influence tactics-job performance relationship. Journal of Leadership \& Organizational Studies, 10(1), 1-18.

Creswell, J. W. (2003). Research design: Qualitative, quantitative, and mixed methods approaches. Thousand Oaks, CA: Sage.

Dağlı, E. ve Çalık, T. (2016). İlköğretim okullarında müdürlerin kullandıkları etkileme taktiklerinin öğretmenlerin örgütsel vatandaşlık davranışları ve okul farkındalığı ile ilişkisi. Kuram ve Uygulamada Eğitim Yönetimi Dergisi, 22(1), 29-58.

Egri, C.P., Ralston, D.A., Murray, C.S., \& Nicholson, J.D. (2000). Managers in the NAFTA countries A cross-cultural comparison of attitudes toward upward influence strategies. Journal of International Management, 6, 149-171.

Falbe, C.M., \& Yukl, G. (1992). Consequences for managers of using single influence tactics and combinations of tactics. Academy of Management Journal, 35(3), 638-652.

Farmer, S.M., \& Maslyn, J.M. (1999). Why are styles of upward influence neglected? Making the case for a configurational approach to influences. Journal of Management, 25(5), 653-682.

Farmer, S.M., Maslyn, J.M., Fedor, D.B., \& Goodman, J.S. (1997). Putting upward influence strategies in context. Journal of Organizational Behavior, 18(1), 17-42.

Higgins, C.A., Judge, T.A., \& Ferris, G.R. (2003). Influence tactics and work outcomes: A meta-analysis. Journal of Organizational Behavior, 24(1), 89-106.

Hoy, W.K., \& Miskel, G. (2010). Eğitim yönetimi teori, araştırma ve uygulama. S. Turan (Çev. Ed.). Ankara: Nobel.

Kipnis, D., \& Schmidt, S.M. (1988). Upward-influence styles: Relationship with performance evaluations, salary, and stress. Administrative Science Quarterly, 33, 528-542.

Kipnis, D., Schmidt, S.M., \& Wilkinson, I. (1980). Intra organizational influence tactics: Explorations in getting one's way. Journal of Applied Psychology, 65(4), 440-452.

Krishnan, V.R. (2004). Impact of transformational leadership on followers' influence strategies. Leadership \& Organization Development Journal, 25(1), 58-72.

KuruÇetin, S., ve Çınkır, Ş. (2014). Okul yöneticileri ve öğretmenlerin birbirlerini etkileme taktiklerinin örgütsel adalet ile ilişkisi. Mehmet Akif Ersoy Üniversitesi Eğitim Bilimleri Enstitüsü Dergisi. 5, 50-64.

McFarland, L.A., Ryan, A.M., \& Kriska, S.D. (2002). Field study investigation of applicant use of influence tactics in a selection interview. The Journal of psychology, 136(4), 383398.

Milli Eğitim Bakanlığı Rehberlik ve Denetim Başkanlığı ile Maarif Müfettişleri Başkanlıkları Yönetmeliği [MEB]. (24.05.2014). Resmi Gazete, Sayı: 29009.

Patton, M.Q. (2002). Qualitative research \& evaluation methods. Thousand Oaks, CA: Sage

Ralston, D.A., Giacalone, R.A., \& Terpstra, R.H. (1994). Ethical perceptions of organizational politics: A comparative evaluation of American and Hong Kong managers. Journal of Business Ethics, 13(12), 989-999.

Ralston, D.A., Gustafson, D.J., Mainiero, L., \& Umstot, D. (1993). Strategies of upward influence: A cross-national comparison of Hong Kong and American managers. Asia Pacific Journal of Management, 10(2), 157-175. 
Ralston, D.A., Hallinger, P., Egri, C.P., \& Naothinsuhk, S. (2005). The effects of culture and life stage on work place strategies of upward influence: A comparison of Thailand and the United States. Journal of World Business, 40(3), 321-337.

Ralston, D.A., Vollmer, G. R., Srinvasan, N., Nicholson, J.D., Tang, M., \&Wan, P. (2001). Strategies of upward influence a study of six cultures from Europe, Asia, and America. Journal of Cross-Cultural Psychology, 32(6), 728-735.

Robbins, S.P., \& Judge, T.A. (2012). Örgütsel davranış. İ.Erdem (Çev. Ed.). Ankara: Nobel.

Sandelowski, M. (2008). Member check. In Lisa M. Given (Ed.), The Sage Encyclopedia of Qualitative Research Methods. (pp. 502-503). Thousand Oaks, CA: SAGE Publications, Inc. doi: http://dx.doi.org/10.4135/9781412963909.n257

Smith, A.N., Watkins, M.B., Burke, M.J., Christian, M.S., Smith, C.E., Hall, A., \& Simms, S. (2013). Gendered influence: A gender role perspective on the use and effectiveness of influence tactics. Journal of Management, 39(5), 1156-1183.

Somech, A., \& Drach-Zahavy, A. (2002). Relative power and influence strategy: The effects of agent/target organizational power on superiors' choices of influence strategies. Journal of Organizational Behavior, 23(2), 167-179.

Steizel, S., \& Rimbau-Gilabert, E. (2013). Upward influence tactics through technologymediated communication tools. Computers in Human Behavior, 29(2), 462-472.

Thacker, R.A., \& Wayne, S.J. (1995). An examination of the relationship between upward influence tactics and assessments of promotability. Journal of Management, 21(4), 739756.

Van Knippenberg, B., \& Steensma, H. (2003). Future interaction expectation and the use of soft and hard influence tactics. Applied Psychology, 52(1), 55-67.

Van Knippenberg, B., Van Eijbergen, R., \& Wilke, H. (1999). The use of hard and soft influence tactics in cooperative task groups. Group Processes \&Intergroup Relations, 2(3), 231-244.

Van Knippenberg, B. M.,Knippenberg, D.V., Blaauw, E., \& Vermunt, R. (1999). Relational considerations in the use of influence tactics. Journal of Applied Social Psychology, 29, 806-819.

Yagil, D. (2006). The relationship of abusive and supportive workplace supervision to employee burnout and upward influence tactics. Journal of emotional abuse, 6(1), 49-65.

Yukl, G., Chavez, C., \& Seifert, C.F. (2005). Assessing the construct validity and utility of two new influence tactics. Journal of Organizational Behavior, 26(6), 705-725.

Yukl, G. \& Falbe, C.M. (1990). Influence tactics and objectives in upward, downward, and lateral influence attempts. Journal of Applied Psychology, 75 (2), 132-140.

Yukl, G., Kim, H., \& Falbe, C.M. (1996). Antecedents of influence outcomes. Journal of Applied Psychology, 81(3), 309-317.

Yukl, G., Seifert, C.F., \& Chavez, C. (2008). Validation of the extended influence behaviour questionnaire. The Leadership Quarterly, 19(5), 609-621.

Yukl G. \&Tracey J.B. (1992). Consequences of influence tactics used with subordinates, peers, and the boss. Journal of Applied Psychology, 77 (4), 525-535.

\section{ExtendedAbstract}

\section{Introduction}

The employment of influence tactics is one of the common phenomena throughout various workplaces. Yukl, Chavez and Seifert (2005) defined the concept of influence tactic as "the type of behavior one person (the 'agent') uses to influence the attitudes or behavior of another person (the 'target')" (p.705). Power is another concept which is related to but different from influence tactic. Power is defined as a person's potential to make others do what he wants (Hoy \& Miskel, 2010). Somech and Drach-Zahavy (2002) explained the difference between power and influence tactics as the first one is the agents' inferred potential, while the latter is their actual behavior aimed at behavioral or attitudinal change in the target. 
Higgins, Judge and Ferris (2003) argued that the measurement of influence tactics began with Kipnis, Schmidt and Wilkinson's (1980) categorization, which included following eight tactics:

Assertiveness. The agent uses a forceful manner to get what he or she wants.

Ingratiation. The agent uses behaviors to ingratiate himself with the target.

Rationality. The agent uses data and information in order to persuade the target.

Sanctions. The agent uses punishment or the threat of punishment to force the target to do his or her wishes.

Exchange. The agent offers something in return for the target's compliance.

Upward appeals. The agent resorts to the help of superiors in his or her efforts to persuade the target.

Blocking. The agent creates difficulties in order to prevent the target's process.

Coalitions. The agent mobilizes other people in his or her efforts to persuade the target.

Another group of tactics can be found in Influence Behavior Questionnaire (Yukl, Lepsinger \& Lucia, 1992). Yukl, Seifert and Chavez (2008) defined the tactics that appeared solely in Influence Behavior Questionnaire as follows: compliance.

Inspirational appeals. The agent plays on the target's values and ideals to gain his or her or her support.

Consultation. The agent seeks the target's participation in the process in order to get his

Personal appeals. The agent tries to influence the target by drawing on his or her friendship with the target.

Legitimating. The agent supports his or her demand by establishing its legitimacy.

Collaboration. The agent offers the target assistance or resources in exchange of his or her compliance.

Apprising. The agent tries to persuade the target by explaining the possible benefits of carrying out the request on the part of the target.

Influence tactics were found to be determinative in assessments of promotability (Thacker \& Wayne, 1995). On the other hand, subordinates might also resort to forceful influence tactics when they face supervisors' abusive behaviors (Yagil, 2006). As for the outcomes of specific tactics, the relevant literature showed that ingratiation was useful in terms of career success (Judge \& Bretz, 1994). Rationality is also positively related to promotability while assertiveness is likely to bring negative outcomes (Alshenaifi \& Clarke, 2014). Falbe and Yukl (1992) found that the most effective tactics were inspirational appeal and consultation, while pressure, legitimating and coalition were the least effective ones. Higgins, Judge and Ferris (2003) argued that combining ingratiation and rationality increases the likelihood of obtaining positive work outcomes.

These study results and many others which are not presented in this summary due to space limitations reveal the importance of influence tactics in work life. When viewed from the standpoint of educational administration, supervision of schools without losing objectivity is of great importance in terms of both legal conformity and effective inspection of schools. This being the case, investigation of principals' influence tactics in the face of educational supervisors may make a contribution to the success of supervision process. However, there is an apparent lack of research both in national and international literature on this subject. Starting from this gap in the relevant literature, the aim of this study is to understand from the perspectives of a number of educational supervisors that:

(1) whether or not principals use influence tactics towards educational supervisors, and if so,

(2) what are these tactics,

(3) what are the factors that affect the selection of the tactics; and

(4) what are the effects of those tactics on the participants. 


\section{Method}

Because of its explorative nature, qualitative methodology was adopted for the present study. The participants were 9 education supervisors who were currently serving in a central Anatolian city in Turkey. In order to address the diversity of supervisors' backgrounds, the participants were varied in terms of seniority, level of education and union.

After they have received the gatekeeper permission from related Provincial Directorate of National Education, one of the two researchers began semi-structured interviews with the supervisors who agreed to participate in the study. At the beginning of each interview, the participants were given an informed consent form. Interviews took place within June, 2015 and lasted 70,4 minutes on average. After the audio files were transcribed verbatim, content analysis was carried out using Nvivo8. In order to enhance the rigor of the study, the draft of findings was sent to the participants' email addresses and they were asked whether or not they object to any part of the draft.

\section{Result and Discussion}

The study's findings were presented under the broad categories of "Tactics used by principals and their influence on educational supervisors" and "Factors that are determinative in principals' selection of tactics". Based on the participants' statements, four broad tactic categories were identified as follows:

(a) Treating the supervisor well: This tactic was subdivided into two tactics:

a. Treating the supervisor well by attentive behaviors: This tactic includes the principal's sincerely polite behaviors such as allocating his or her own office for supervisors in order to provide them with a comfortable work environment.

b. Treating the supervisor well by cunningness: This tactic includes behaviors such as developing an overly submissive attitude in the face of supervisors or flattering them with comments.

(b) Exhibiting his/her own achievements: Some principals are reported to display their achievements before they were asked.

(c)Implying his/her power: This tactic was also subdivided into two tactics:

a. Implying expert power: Some principals who have deep principalship experience are claimed to try to influence supervisors by displaying their knowledge and experience.

b. Implying relational power: Some principals are reported to mention their intimacy with their superiors or with a particular influential union.

(d) Establishing intimacy with the supervisor by mentioning their similar backgrounds: Particularly at the beginning of inspection process, some principals reportedly try to establish intimacy with supervisors by mentioning their similar backgrounds such as being from the same city or having the same acquaintances.

The results of content analyses suggested that factors that are determinative in principals' selection of the tactics can be collected under three headings: (a) personal factors which included seniority in principalship, gender, culture, level of social skill and level of competence, (b) characteristics of the school, and (c) supervisors' attitudes.

Findings of the present study indicated that the participants shared some similar perceptions about principals' influence tactics. These perceptions -to a certain extent- are coherent with the tactics identified in the relevant literature. For example both "treating supervisor well" and "establishing intimacy with the supervisor" match up with ingratiation, while "exhibiting his/her own achievements" is quiet similar to "rationality". On the other hand, "implying his/her power" emerged as a new tactic that may be elaborated in future researches. 